\title{
The impact of emotional intelligence on effective leadership in the military production factories (MPF) in Egypt
}

\author{
Safaa Shaaban \\ Business Department, The British University in Egypt, Cairo, Egypt
}

\section{Keywords}

Emotional intelligence, transfer leadership, transactional leadership

\begin{abstract}
Emotional intelligence is one of the most important personal trait linking to leadership in a way of assisting and developing the desired skills needed for those leaders applying effective leadership. There is a lack in the research literature related to leadership style in the Military Production Factories (MPFs) sector in Egypt. There is great attention and initiative to the reform in governmental sector in Egypt. This study considered as a baseline study for identifying the dominant leadership style in MPF. Military production industry sector includes 20 factories and companies lead by the Ministry of Military production (MOMP). The factories produced Military and non-military production. The sector includes 33546 employees. The selected organisation (MPF) works under the authority and supervision of the Ministry of military production (MOMP) in Egypt, however the majority of worker, including top, and middle line management are civilian. This study investigates the style of leadership mainly transformation and transactional leadership. The scale of the questionnaire was developed based on two sources and references to measure this relationship between the independent variable emotional intelligence and dependent variable leadership style. This study uses statistical tools SPSS including regression, correlation, Cronbach's alpha.

The result on the level of Leadership, First, -study shows that female employee of the MOMP have a tendency towards a high level of transformational leadership style behavior more than male managers in the MOMP. Confirmed by Mandell and Pherwani, 2003). Second, Males' leadership style more oriented to the style of transactional style of leadership (confirmed by Strickland, 2008). On the level, emotional intelligence females scored higher than male in emotional intelligence. Furthermore, the dimensions of emotional intelligence (emotion attention, emotional clarity and Emotional repair (women scoring higher in emotional repair the most).
\end{abstract}

Corresponding author: Safaa Shaaban

Email addresses for corresponding author: Safaa.shaban@bue.edu.eg

First submission received: $19^{\text {th }}$ December 2017

Revised submission received: $7^{\text {th }}$ March 2018

Accepted: $5^{\text {th }}$ April 2018

\section{Introduction}

One of the crucial traits to develop in an effective leader is Emotional Intelligence. Understanding Emotional Intelligence has become a critical tool for managers. It is considered valuable in building an effective leader. The academic literature contains numerous studies of and various theories of leadership addressing the characteristics of the most effective leadership style. The literature agrees that the most effective leadership styles are transformational and transactional leadership (Batool, 2013).

The style of a transformational leader, which has created interest among researchers and scholars, is to inspire a diverse view and attitude in the workplace, create an awareness of organisational goals, react with other followers at a high level and motivate others to adapt the idea of putting their organization's goals before their personal goals (Bass \&Avolio, 1994). The style of a transactional leader is premised on the exchange theory, which considers the rewards or discipline based on the manager's performance. Transactional leaders focus on employee performance as a base and as indicators for employee work standards, task completion and compliance while relying heavily on organizational rewards and punishments (Bass \&Avolio, 1994). Scholars studying and examining the effects of transformational and transactional leadership style have found that transformational leaders recorded a higher effectiveness and satisfaction rate than transactional leaders (Hater \& Bass, 1998). Many researchers 
proposed that in the area of leadership, effective transformational leaders must possess Social and Emotional Intelligence which inspires managers to build a strong relationship with leaders (Keller, 1995 and Seltzer \& Bass, 1990).

The question is: Does Emotional Intelligence (EI) help in preparing effective leaders? This question has been raised by many researchers, scholars and authors in the last era (Higgs, 2003). Different factors have been highlighted as important and effective factors in developing effective leaders. The cognitive factor was mentioned by Sternberg \& Vroom, (2002). Another factor such as conscientiousness is mentioned by Barrick\& Mount (1991), while a few studies such as McKee (2005) and Goleman (1998) have identified the role of emotional intelligence (EI). The purpose of this research study is to add to those few studies on the impact of emotional intelligence on developing effective leadership.

Daniel Goleman is a greatest contributor to the concept of emotional intelligence and leadership. Goleman argues that leaders who have high emotional intelligence are the fundamental key for an organisation to reach its success throughout its leaders. Those leaders have the capacity and skills to enable, empower and inspire their managers. They are sensitive to the feelings of their managers, they will intervene in the situation if necessary, and they are able to manage their emotions according to the situation. They gain their managers' trust and they are aware of the political and social frameworks within the organisation (Goleman, 2001).

There are many models in addition to Goleman (1995) which have developed the emotional intelligence concept, such as the Mayer and Salovey (1997) model and the Bar-On's (2006) model. This study will use the Trait Meta-Mood Scale (TMMS) which was developed by Salovey, Mayer, Goldman, Turvey, and Palfai (1995). This model was updated by Fernandez Berrocal et al (2004). The leadership model will be Multi Leadership Questionnaire (MLQ) which covers the transformational and transaction leadership style adopted by Van Knippenberg \& Sitkin (2013).

This study objective is to test emotional intelligence and its impact on developing an effective leadership programme for the future leaders of the MPF and to test if the relationship between emotional intelligence and transformational leadership is higher than the relationship between emotional intelligence and transactional leadership in the MPF in Egypt.

\section{Literature Review}

\section{2-1 Emotional intelligence}

In 1990, Mayer and Salovey published a paper laying the groundwork for the theory of Emotional Intelligence (EI). Between 1994 and 1997, the concept of EI was promoted and adapted by psychologist and journalist Daniel Goleman (1995). Goleman presented this concept of EI in his book "Emotional Intelligence." During this time Goleman presented a new definition for "Emotional Intelligence" (EI). He defined EI as the ability to identify, assess, and control one's own emotions, the emotions of others, and that of groups" (Goleman, 1995).

EI focuses on social behaviour. Since 1997 there has been much interest in the concept and a lot of questions aside, especially by Mayer and Salovey (1997). EI is used very popularly in measures of empathy, sociability, optimism, motivation and leadership (Mayer, 2001). Gayathri and Meenakshi referred to the Mayer and Salovey model as an 'ability' model, the Goleman and Bar-On model as a mixed model, while Goleman's model is referred to as a competency model and Bar-On's as a trait model (2013, p.46). Emotional intelligence is considered as the most likely logical framework to build the targeted intelligence criteria throughout the establishing of emotional construction for the purpose of leadership effectiveness, in other words for establishing emotional intelligence for the purpose of measuring leadership effectiveness. (Jordan, 2000).

Several studies and researchers have developed many modules of EI. Goldman stated, in his book "Emotional Intelligence," that EI is a matter of more than an IQ. Gayathri and Meenakshi said that, "(i)t is a matter more than IQ" in 1995 with claims bordering on hyperbolic sometimes, making the sweeping statement that EI was the reason for "nearly $90 \%$ of the difference" between star performers and average performers (Gavathri and Meenakshi 2013, P. 46).

In 1994 Mayer and Stevens developed the Meta-Regulation Scale (MRS) that analysed and focused on two things. First, it addressed how the thoughts of an individual can be affected by his/her mood situation in understanding the different type of conscious mood guideline. Second, it addressed how an 
effective capacities stability, which individuals usually use to practice their moods and feeling (Berrocal and Extremera, 1995).

The three factors of Trait Meta-Mood Scale (TMMS) were identified by Salovey, Mayer, Goldman, Turvey, and Palfai (1995). Their scale module is described in three dimensions (Attention, Clarity, and Repair). The module is designed to measure the effect of the emotions of people based on their moods and identified the value and feelings according to their extent (Attention), how they feel clear slightly than feeling confusion (Clarity), and people apply the positive thinking to repair or to fix their negative moods (Repair). Salovey, P., Mayer, J. D., Goldman, S. L., Turvey, C., and Palfai, T. P. (1995) gives an adequate core consistency of its scale with convergent and discriminant validity. Salovey in his study also validated the Spanish shorter version of the TMMS (Fernández-Berrocal, P., Extremera, N., \& Ramos, N., 2004). Originally, the scale had 48 items which were subjected to many criticisms. This current research study will apply the shortened Spanish version and includes 24 items from the original version (eight for each subscale), and shows high internal consistency (Cronbach's alpha for Attention $=.90$, Clarity $=.90$, Repair $=.86$ ) and satisfactory test-retest reliability ( $\mathrm{r}$ values from .60 to .83) (Balluerka et al., 2016)

\section{2-2 Leadership}

This study utilizes the variables of the contemporary style of leadership developed by Lewin et al. (1939) as follows:

2.2.1 The transformational leadership style of leadership has its own techniques, approaches and strategy that depend on leaders' vision and at the same time focuses on empowerment, changing values, norms and attitudes. This style also enhances the self-efficacy of its followers.

Transformational leaders are concerned with developing a vision which matches with their organisation's mission. Both mission and vision are developed based on the institution for the organisation's techniques, policy and strategies. The transformational leadership style is creative and passionate. Transformational leaders motivate their managers with the approach of intrinsic motivation ability (Howell and Avolio, 1993).

Transformational leadership is distinguished from another type of leadership which is charismatic leadership as cited by (Bahmanabadi, 2015). Yammarino (1994. P 39) believes, "the individual characteristics of charismatic leaders include a high degree of self-confidence, strong moral convictions, and the ability to influence others. This also is involved in management behaviours, with the purpose of affecting others to increase their trust in the leader".

According to Tichy \& Devanna (1996), a transformational leader's style characteristic is proactive, helping followers or managers to achieve extraordinary goals by raising their awareness for transcendent collective benefits. The style of transformational leadership is argued to include five first-order factors as follows:

A. Intellectual stimulation which relates to the leader who challenges his/her followers to a sense of logic and who challenges their creativity in finding solutions to hard problems and obstacles; and

B. Individualised consideration, which refers to the behaviour of the leader, which adds to the satisfaction of followers throughout the process by paying attention, supporting, coaching and advising. Therefore, this allows followers to achieve self-actualization and increases their selfesteem.

C. Inspirational motivation which relates to how leaders empower their followers by perceiving an optimistic future, setting ambitious goals and objectives, encouraging dreaming, and convincing their followers that this vision and these objectives are reachable.

D. Idealised influence (attribute) which reflects the characteristics of the leader. If he/she has socialisation charisma, he/she is viewed as being powerful and self-confident, or he/she is perceived as concentrating on ideals and ethics.

E. Idealised influence (behaviour) which discusses the issues of the charismatic leader and focuses on mission, vision, beliefs;

This research study will focus on the first three dimensions as they are related to leaders' behaviour towards their followers. 


\section{2-3 The relationship between emotional intelligence and effective leadership}

Goleman (1998) drew attention to the fact that effective leaders have a high level of Emotional Intelligence. Moreover, many researchers have agreed that, for a person to develop a great relationship with his colleagues, this person should have good interpersonal and social skills as well as good team building skills. Also, leaders who have these skills will have high influence on subordinates which is essential for a person's success in the workplace and outside (Emmerling and Goleman, 2003; Cherniss, C., Goleman, D., Emmerling, R., Cowan, K \& Adler, M., 1998; Boyatzis and Oosten, 2002).

Other scholars and studies confirmed that the most effective leaders, those that have a positive impact, have a high level of emotional intelligence (EI) (Van Oosten 2013; Drucker 2008; Collins 2001; Kerr, Garvin, Heaton \& Boyle 2005; Goleman 1995; Ruderman et. al, 2001). While other scholars such as Antonakis (2004) point out that empirical evidence in support of the relationship between EI and leadership remains weak, even after many years of research, other researchers not been successful in identifying statistical support for the significance relationship of EI on effective leadership. (Brown, Bryant \& Reilly 2006; Barbuto \& Burbach 2006)

According to studies by Goleman $(1995,1998)$ and Palmer, Walls, Burgess and Stough (2001), there is a clear sign of a relationship between emotional intelligence and leadership. Other support for this relationship is provided by the South African research of Coetzee and Schaap (2005). Ramchunder and Martins (2014), Stuart and Paquet (2001) and Vrba (2007) also validate these findings on the relationship between EI and leadership.

A number of researchers and studies such as Barling, et al, state that leaders who have high emotional intelligence are able to direct and energize people. The reason why leaders high in emotional intelligence adhere to transformational behaviours is implicit. Leaders with the characteristics of selfcontrol and self-management ability are very much consistent with the first dimension (idealized), which is the more dimension has impact on the followers (Barling, J., Slater, F., Kelloway, E. K., 2000). Particularly, when leaders are able to understand their own emotional and their follower's Emotional Intelligence or they aware when to be emotionally close and helpful/ kind to the people, improve trust and confidence, motivation, and commitment, and performance as a model of these values (Naznin, 2013). The second dimension is an individualised consideration, leaders who have the skills to manage a relationship positively with their follower will be able to show individual consideration toward their followers (Harms and Crede, 2010, p.7). The third dimension of the transformational style is inspirational motivation and their recognition of their Emotional and other Emotional will help them to inspire and build the relationship (Wang and Huang, 2003, p. 382).

\section{Theoretical Framework:}

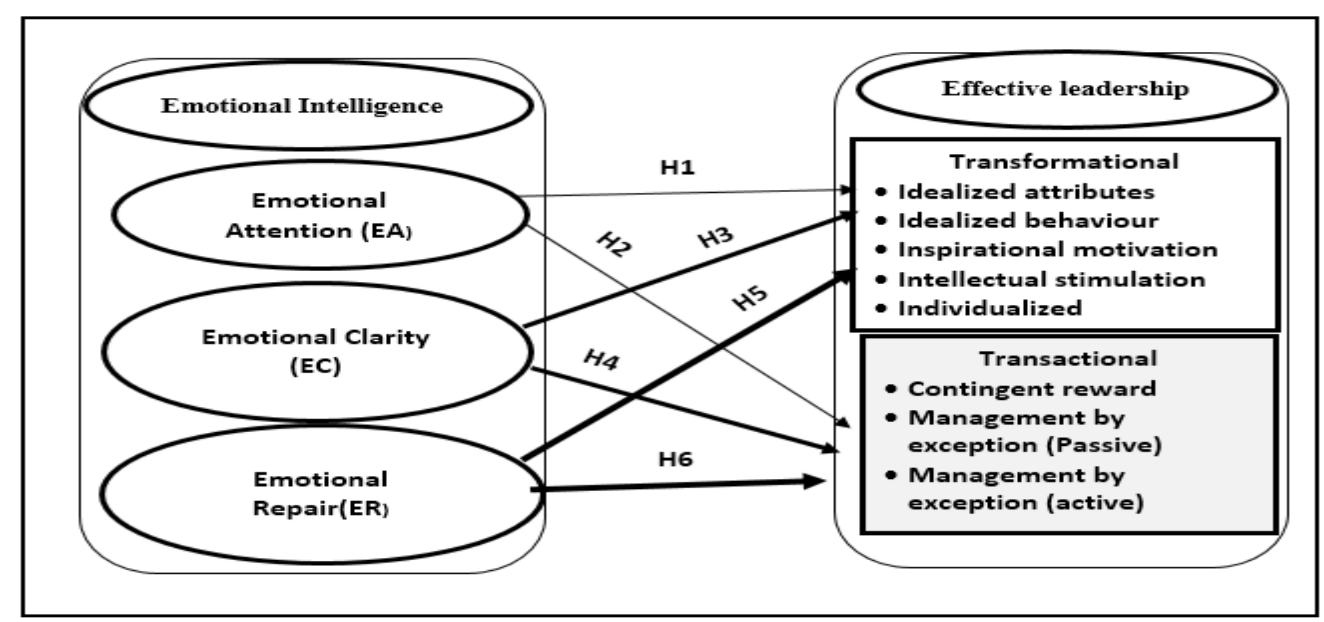

Figure 1: Theoretical framework for the study developed by the researcher

Bases on the research study objectives and literature review, the theoretical framework of this research study developed as shown in figure 1, it is implicit that there is relationship and main influence 
of the emotional intelligence (Emotional attention (EA), Emotional Clarity (EC) and Emotional Repair (ER). The two-leadership style are transformational leadership style that included (idealized influence, inspirational motivation, intellectual stimulation, and individualized consideration), which is the desire leadership style. While the second leadership style is (transactional leadership which includes (conditional reward, active management by exception, and passive management by exception.

The variables in this study consist of the independent variables related to emotional intelligence includes 3 dimensions and the dependent variables related to leadership style (transformational and transactional leadership style).

\section{Research problem:}

Leadership is vitally important in business settings. Leadership acts as the catalyst that makes all other elements work together. To the best of the author's knowledge, there has been no previous research about leadership style in the sector. There is a significant amount of research on leadership (Yuki, 1998; Yuk\&Van Fleet, 1992). The Egyptian MOMP aims to improve their current business and open new production lines. The current taskforce is neither equipped nor prepared for this new strategy and structure.

Recently, there have been many leadership programs developed to be implemented in the governmental sector in response to the government's new strategy (2030). These programs have failed to achieve their goals because of the lack of baseline studies to determine the nature of the managers in these organisations. This is why emotional intelligence is important in designing and delivering effective leadership. Managers need to be aware of the level of emotional intelligence in order to deliver their leadership style in MOMP.

\section{Methodology}

\subsection{Study Objectives}

- To identify the leadership style within the MOMP;

- To test the current level of emotional intelligence of the MOMP managers;

- To examine the manager's emotional intelligence and its relationship with leadership style within the MOMP.

- To identify differences in leadership style according to gender

\subsection{Research Hypothesis}

The hypotheses in this research study were developed to explore the relationships and connections between emotional intelligence and effective leadership (transformational/ transactional) in the MPF, six hypotheses were developed and shown below:

H1: Emotional Attention has a positive impact on Transformational Leadership

H2: Emotional Clarity has a positive impact on Transformational Leadership

H3: Emotional Repair has a positive impact on Transformational Leadership

H4: Emotional Attention has a positive impact on Transactional Leadership

H5: Emotional Clarity has a positive impact on Transactional Leadership

H6: Emotional Repair has a positive impact on Transactional Leadership

\subsection{Sample}

The research was conducted at the beginning of 2017 by survey. This research targeted $(N=500)$ managers. The questionnaire was randomly distributed to 200 managers, of which only $\mathbf{1 5 0}$ answered in a usable manner. The gender of the respondents was representative of the population (respondents were $33 \%$ female and $67 \%$ male).

\subsection{Instruments}

The survey contained three sections, containing a total of 96 questions divided into three sections.

First Section: included demographical data such as age, qualification and gender,

Second Section: included 48 questions divided into 3 parts for Emotional intelligence scale adapted from Salovey et al., (1995),

Third Section: included 45 questions adapted

from the Multifactor Leadership Questionnaire (MLQ) by Van Knippenberg \& Sitkin (2013) 
The questions were close-ended using a five-point Likert scale where $1=$ strongly agree and $5=$ strongly disagree.

A special questionnaire was designed containing 85 questions divided into three sections. The First section included demographic information including age, qualification and gender. The Second section which related to EI using TMMS-24 (Trait- Meta-Mood Scale) adapted from Berrocal et al, (2004), this scale assesses three dimensions comprised of (1) Emotional attention including 8 statements, which related to an individual tends to think about his feeling and moods. (2) Emotional attention including 8 statements that related to the person's evaluation of his/her Emotional conditions. (3) Emotional repair includes 8 statements, related to the person believed that he/she regulates his Emotion and feeling. Third section in the questioner measuring the leadership style including 45 questions and was adapted from Multifactor Leadership Questionnaire (MLQ) by (Van Knippenberg \& Sitkin (2013).

\section{5-Results:}

5-1 Reliability and Validity:

The check was carried out using the SPSS for assessing the reliability and validity of all the variables.

Table (1): Reliability and Validity Analysis for all variables

\begin{tabular}{|c|c|c|c|c|c|c|c|c|c|c|c|c|c|c|}
\hline Scale & E I & $\overline{E A}$ & $\overline{\mathrm{EC}}$ & $\overline{\mathrm{ER}}$ & 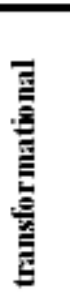 & 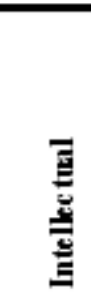 & 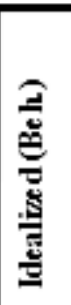 & 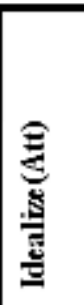 & 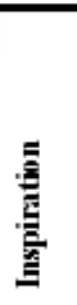 & 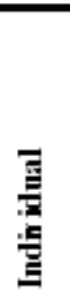 & 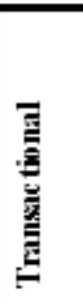 & 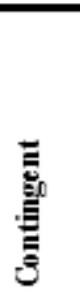 & 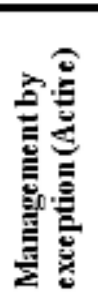 & 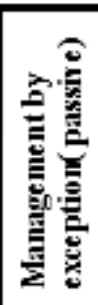 \\
\hline Alpha & .705 & .601 & .714 & .869 & .905 & .850 & .788 & .772 & .857 & .729 & .607 & .646 & .691 & .692 \\
\hline
\end{tabular}

\section{4-2 Correlation analysis:}

Table (2): Correlation of the three variables of the research

\begin{tabular}{|c|c|c|c|c|c|c|c|c|c|c|c|c|c|c|c|c|c|}
\hline & Mean & SD & 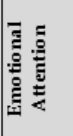 & 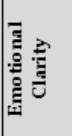 & 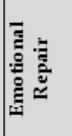 & 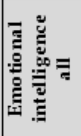 & 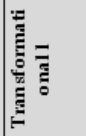 & 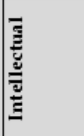 & 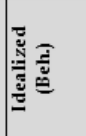 & 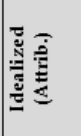 & 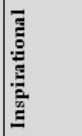 & 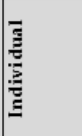 & 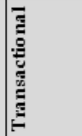 & 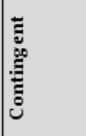 & $\frac{\text { 폽 }}{\bar{\Sigma}}$ & 逹 & 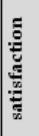 \\
\hline $\begin{array}{l}\text { Emotional } \\
\text { Attention }\end{array}$ & 24.7965 & 4.63712 & 1 & & & & & & & & & & & & & & \\
\hline Emotional Clarity & 31.4602 & 4.26161 & $.323^{\prime \prime}$ & 1 & & & & & & & & & & & & & \\
\hline Emotional Repair & 30.3451 & 4.14636 & $.257^{2 t}$ & $.539^{n+1}$ & 1 & & & & & & & & & & & & \\
\hline $\begin{array}{l}\text { Emotional } \\
\text { intelligence all }\end{array}$ & 112.5664 & 13.81050 & $.660^{27}$ & $.744^{27}$ & $.574^{27}$ & 1 & & & & & & & & & & & \\
\hline Transformational & 3.6742 & .753 & $.625^{\prime \prime}$ & $.758^{\prime \prime}$ & $.859^{27}$ & .901 & 1 & & & & & & & & & & \\
\hline Intellectual & 14.7611 & 4.02065 & .176 & .029 & -.042 & .021 & $.891^{72}$ & 1 & & & & & & & & & \\
\hline Idealized (Beh.) & 15.1150 & 3.22311 & .095 & .092 & .107 & .091 & $.849^{72}$ & $.682^{72}$ & 1 & & & & & & & & \\
\hline Idealized (Attrib.) & 15.5044 & 3.41249 & .056 & .055 & .015 & -.010 & $.847^{r 2}$ & $.653^{27}$ & $.651^{x z}$ & 1 & & & & & & & \\
\hline Inspirational & 15.3186 & 3.83654 & .154 & .019 & .010 & .048 & $.907^{x *}$ & $.799^{x *}$ & $.720^{* x}$ & $.708^{7 z}$ & 1 & & & & & & \\
\hline Individual & 13.5929 & 2.68474 & .061 & .077 & .045 & .057 & $.790^{7 *}$ & $.629^{72}$ & $.609^{n z}$ & $.632^{2 x}$ & $.617^{2 x}$ & 1 & & & & & \\
\hline Transactional & 44.5133 & 6.08587 & .095 & .018 & -.087 & .075 & $.616^{22}$ & $.612^{72}$ & $.511^{* 2}$ & $.462^{7 x}$ & $.548^{72}$ & $.497^{72}$ & 1 & & & & \\
\hline Contingent & 14.9027 & 2.80613 & .143 & .080 & .044 & .111 & $.772^{72}$ & $.736^{72}$ & $.726^{72}$ & $.567^{3 z}$ & $.707^{22}$ & $.556^{72}$ & $.665^{2 x}$ & 1 & & & \\
\hline MBEP & 8.5841 & 3.66627 & -.019 & .035 & -.035 & .075 & $-.605^{* *}$ & $-.510^{n *}$ & $-.518^{* 4}$ & $-.560^{n t}$ & $-.597^{7 n}$ & $-.387^{n *}$ & .020 & $-.450^{x "}$ & 1 & & \\
\hline MBEA & 13.4336 & 3.73180 & -.018 & -.086 & -.151 & -.057 & $.560^{72}$ & $.521^{x z}$ & $.429^{* *}$ & $.471^{7 x}$ & $.513^{n z}$ & $.464^{x ?}$ & $.794^{\prime *}$ & $.391^{7 *}$ & $.323^{72}$ & 1 & \\
\hline satisfaction & 7.5929 & 2.00730 & .155 & .038 & .017 & .042 & $.851^{72}$ & $.788^{7 x}$ & $.684^{x *}$ & $.758^{72}$ & $.811^{12}$ & $.572^{x \geq}$ & $.590^{x 2}$ & $.713^{x 2}$ & $-.626^{m 4}$ & $.503^{n+}$ & 1 \\
\hline
\end{tabular}

Although the statistics in Table 1 show that the questions are valid and reliable, the correlation statistics in table (2) shows that there is a correlation between EI and Transformational Leadership style rather than Transactional Leadership style.

\section{4-3 Regression analysis:}

Table (3) Total Leadership Style Scores by Gender $(n=150)$ 


\begin{tabular}{|l|l|l|l|l|l|l|}
\hline Construct & Gender & $\mathbf{n}$ & M & SD & Minimum & Maximum \\
\hline \multirow{2}{*}{$\begin{array}{l}\text { MLQ- } \\
\text { Transformational }\end{array}$} & Female & 54 & 3.6959 & .23889 & 3.1500 & 4.1709 \\
\cline { 2 - 7 } & Male & 96 & 3.6637 & .75677 & 3.6396 & 3.6867 \\
\hline \multirow{2}{*}{$\begin{array}{l}\text { MLQ- } \\
\text { Transactional }\end{array}$} & Female & 54 & 45.4054 & .77786 & 43.6276 & 46.9519 \\
\cline { 2 - 7 } & Male & 96 & 45.4054 & 5.89001 & 42.7703 & 45.4456 \\
\hline
\end{tabular}

The leadership style scores had a range of each style. The range of scale recorded for the respondent for the transformational style of leadership was 3.1500 to 4.1709 . Transactional style of leadership score recorded from 42.7703 to 46.9519 . Therefore, the transformational style of leadership scored higher than the transactional style of leadership.

The relationship between variables:

(EI)

(Transformational leadership)

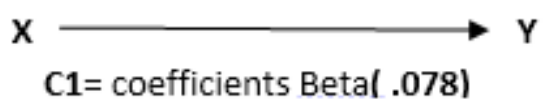

Figure 2: The relationship between variables

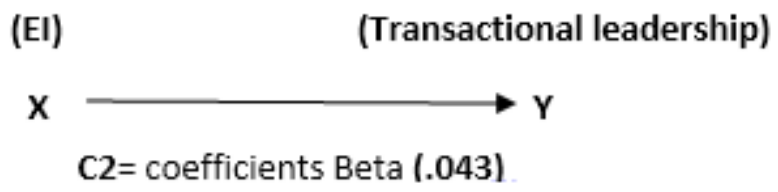

Figure 3: The relationship between variables

Regarding the hypotheses 1, 2 and 3 stated that " there is a significant and positive impact of EI dimensions on Transformational Leadership", the statistics results shows that supported by Table 2, 3 and diagram 2, the relationship between EI dimensions ( attention, clarity and repair) and transformational leadership style dimensions (idealized influence, inspirational motivation, intellectual stimulation, and individualized consideration) is significant which proves Hypotheses 1, 2 and 3 stated that there is a significant and positive relationship between the three dimensions of EI and transformation leadership, theses finding in alignment with other studies such as Fariborzi (2003), Garner and Stough (2002), Day Newsome and Catano (2002), Goleman (1995) and Bassand Avolio (1995). Figure 2 shows the regression analysis and formula of the relationship between EI and transformational that translated by (C1) is higher that, in figure 3 the regression analysis and formula of the relationship between EI and transactional style translated by (C2). This confirms that the transformational leadership style is recorded higher score than the transactional leadership style in this sample group, furthermore justification will appear in the discussion. Therefore, the hypotheses 1,2 and 3 are accepted.

On three hypotheses 4, 5 and 6 stated that "there is a significant and positive impact on Transactional Leadership", the statistic results indicate that as shows Table 3) shows that the EI and transactional style are not significant. The correlation coefficient and relationship between dimensions of emotional intelligence (attention, clarity and repair) and dimensions of transactional leadership style (conditional reward, active management by exception, and passive management by exception) not significant nor positive. These findings match to the results of the other studies such as Garner \& Stough (2002), Weinberg (2003),), Barling, Slater, and Kelloway (2000). Therefore, the hypotheses 4,5 and 6 not supported and rejected. However, this result not in alignment with other result and findings of other result study such as of Coetzei \& Schaapp (2005).

\section{5- Discussion}

One of the most crucial competencies for effective leadership is Emotional Intelligence (EI) and many studies mention that many leadership abilities depend on emotional intelligence abilities (Melita \& Ceasar, et al, 2003). Due to the need for the Military Productions Factory and companies to respond to the dramatic changes in the current business environment, there is a need for the organization to generate more openness and receive new creative ideas and models to improve the business. Also, the MPF is 
required to create and invent new products, services and approaches in the local, regional and international markets. Consequently, they need to reinforce and equip, empower, enable and encourage managers to take the initiative and innovate the MPF businesses. Because the values, beliefs and behaviours of managers are the pillars that contribute to improving the performance of organisations, greater attention should be paid to the role that emotional intelligence plays in the development of leadership competencies as mentioned in the study of Sadr in 2012.

The sample in this study shows that female managers of the MPF tend to exhibit a higher level of transformational leadership style behaviour more than male managers. Therefore, we conclude that females in this study exhibit more of the behaviour of transformational style leaders that men do. This was predictable. A 2003 research study by Mandell and Pherwani confirmed that women are more likely to apply the behaviour of the transformational style of leadership, while the behaviour of males conforms to the transactional style of leadership. Also, Strickland (2008) in her study confirmed this trend. In addition, females' results show that they respond to contingent rewards more than males, which is supported by Eaglet et al. (2003) and Strickland (2008).

This study shows that the emotional intelligence of the females in this study is generally higher than for the males in this sample of managers which supports findings by Cavallo and Brienza, (2006). Although in this study the statistic shows that there is a low level of clarity and repair as dimensions of emotion with the managers in MPF. However, in another study carried out with an American organisation and designed to investigate the role of the emotional experience and cognitive difficulties in acute stress situations, the importance of emotional Clarity was verified again (Gohm, Baumann, and Sniezek, 2001). In reality, individuals with higher levels of emotional clarity reported a lower number of cognitive difficulties such as "to fail to see the point and do not know what to do", "to forget what I learned" or "to be unable to think" (Berrocal\& Extremera, 2008).

Accordingly, this study can support hypotheses 2 and 3 and report that the targeted managers in the MPF are not facing any cognitive difficulties. This knowledge will help in reinforcing the effective leadership competencies and abilities.

The results of this study show that there was a significant relation between emotional intelligence and leadership competencies for leaders in the MPF. The result shows or demonstrates that there is a significant correlation between emotional intelligence dimensions and leadership competencies for managers considered as future leaders for the MPF. This is because the emotional intelligence dimension of 'passionate' is a crucial competency for effective leadership. Different dimensions of emotional intelligence are correlated with leadership competencies and dimensions (Melita \& Ceasar, et al, 2003). This research result is supported by David \& Joseph (2005). These two researchers concluded that there is a significant relationship between emotional intelligence and leadership capabilities. Also, higher emotional intelligence was associated with higher leadership competencies. In addition, Lisa \& Con (2002) identified a high correlation between understanding of emotional intelligence and all of the leadership skills components.

The results of this study show that there is a signification positive relationship between emotional intelligence and transformational and transactional leadership styles. However, the results apply more to transformational than to transactional leadership. The regression results for the transformational style of leadership (beta $=.059, \mathrm{t}$-value $=5.645$, significant $=.533$ ), while for transactional leadership is (beta $=.075$, $\mathrm{t}$-value $=8.629$, significant $=.432$ ). The result shows there is a positive relationship between each of the two constructs (EI and transformational leadership style and EI and transactional leadership style). Accordingly, the hypotheses are accepted.

\section{Implication to Research and Practice}

These study results have many essential practical implications: first, the study contributes to literature by highlighting the role of emotional intelligence in effective leadership in the Military Factories in Egypt. The result could have many theoretical implications, the impact of Gender on emotional intelligence helps in clarifying in respect of the scope and examination of two variables especially in Egypt and in military factories that have the huge workforce number of employees. Second, it helps mangers to manage their emotions toward the desired organizational goals. Goleman suggests that leaders who are evaluated at more than high in emotional intelligence are considered key to organizational success while 
simultaneously achieving their goals. He also pointed out that leaders must have the capacity, as one of their skills, to sense employee's feelings within their work environment. This will help leaders to interfere when problems arise, to be able to direct their own emotions in a way to gain the employees' trust and to realize the organisation's political and social resolutions (Goleman, 2001).

\section{Conclusion}

The main objective of this study was to examine the impact of emotional intelligence skills on the leadership style competency of managers in MPF leaders. Based on the results of this study, the conclusion is that the MPF talent pool group behave more in a manner more consistent with the transformational leadership style than transformational leadership style. Females in the MPF behave more in transformational style rather than transactional style, while the males in MPF prefer to behave in the context of transactional style rather than transformational style. Females in the MPF scored higher in emotional intelligence than males.

\section{Limitations and Future Research}

The following are the limitations of this study. First, one of the limitations of this study is that the sample was selected only from the mangers of MPF, so generalization of the results of this study may be limited to other categories and for mangers in other government ministries because of the different leadership and orientation.

Second, selection criteria and process should take into consideration emotional intelligence as an important criterion in selection and recruitment. Third, Female are more oriented toward transformation leadership, it is recommended that women take more opportunities in these organisation

\section{References}

Avolio, B. J., \& Bass, B. M. (2004). Multifactor leadership questionnaire: Manual and sampler se. (3rded.) Palo Alto, CA: Mind Garden.

Bahmanabadi, S. (2015) a case study of the impact of leadership styles on bank managers' job satisfaction, the Institute of social sciences.

Balluerka N, Gorostiaga A, Alonso-Arbiol I, Aritzeta A. Peer attachment and class emotional intelligence as predictors of adolescents' psychological well-being: A multilevel approach. J Adolesc. 2016 Sep 2; 53:1-9.

Barbuto, J.E. \& Burbach, M.E. (2006). The emotional intelligence of transformational leaders: a field study of elected officials. Journal of Social Psychology, 146(1), 51-64.

Barling, J., Slater, F., Kelloway, E. K. (2000). Transformational leadership and emotional intelligence: an exploratory study. Leadership and Organization Development Journal, 21, 157-161.

Bar-On, R. (2006) The Bar-On model of emotional-social intelligence (ESI). Psicothema, 18:13-25.

Bar-On, R. 2010. Emotional intelligence: An integral part of positive psychology. South African Journal of Psychology, 40(1):54-86.

Barrick, M. R. and M. K. Mount (1991). The Big Five personality dimensions and job performance: A meta-analysis. Personnel Psychology 44(1): 1-26.

Bass, B. \& Avolio, B. (2000). "MLQ: Multifactor leadership questionnaire", 2nd edition, Technical Report. Redwood City, CA: Mind Garden.

Bass, B. M. (1998). Transformational leadership: Industrial, military, and educational impact. Mahwah, NJ: Erlbaum.

Bass, B.M. \& Avolio, B.J. (Eds.). (1994). Improving organizational effectiveness through transformational leadership. Thousand Oaks, CA: Sage Publications.

Batool, B. (2013). Emotional intelligence and effective leadership. Journal of Business Studies Quarterly, 4(3), 84-94.

Berrocal and Extremera (2008) A review of Trait Meta-Mood Research, International Journal of Psychology Research, Volume 2, Issue $1 \frac{1}{2}$. Pp.39-67.

Boyatzis, R., and McKee, A (2002). Primal Leadership: Realizing the power of EI. Boston, Harvard Business School Press.

Boyatzis, R.E. \& Oosten, E. V. (2002). Developing emotionally intelligent organizations. In Roderick Millar (ed.), International Executive Development Programmes, 7th Edition. London: Kogan Page Publishers.

Brown, FW, Bryant, SE \& Reilly, MD. 2006. Does emotional intelligence - as measured by Canada: MHS Publishers.

Cavallo, K., \& Brienza, D. (2004). Emotional competence and leadership excellence at Johnson \& Johnson: The emotional intelligence and leadership study. New Brunswick, NJ: Consortium for Research on Emotional Intelligence in Organizations, Rutgers University.

Cavallo, K., \& Brienza, D. (n.d.). Emotional competencies and leadership excellence at Johnson\& Johnson: The emotional intelligence and leadership study. Consortium for research on Emotional intelligence in 
Organisations. Retrieved September 11, 2006, from www.eiconsortium.org

Cherniss, C., Goleman, D., Emmerling, R., Cowan, K \& Adler, M. (1998). Bringing Emotional Intelligence to the Workplace. A Technical Report Issued by the Consortium for Research on Emotional Intelligence in Organizations. Available http://www.eiconsortium.org

Coetzee, C., \& Schaap, P. (2005). The relationship between leadership behaviour, outcomes of leadership and emotional intelligence. SA Journal of Industrial Psychology/SA Tydskrif vir Bedryfsielkunde, 31(3), 31-38.

Collins, V.L. (2001). "Emotional intelligence and leadership success", Lincoln, Nebraska: University of Nebraska. UMI: 3034371.

David, R., \& Joseph, C., (2005): “Emotional intelligence and its relationship to workplace outcomes of leadership effectiveness", Leadership\& Organisation Development Journal, Vol. 26 Iss: 5, pp.388-399.

Eagly, A. H., Johannesen-Schmidt, M. C., \& van Engen, M. L. (2003). Transformational, transactional, and laissez-faire leadership styles: A meta-analysis comparing men and women. Psychological Bulletin, 129, 569-591.

Emmerling, R. J. \& Goleman, D. (2003). Emotional Intelligence: Issues and Common Misunderstandings. Issues in Emotional Intelligence, [On-line serial], 1(1). Available http://www.eiconsortium.org

EQ-i - influence transformational leadership and/ or desirable outcomes? Leadership and Organizational Development Journal, 27(5):330-351.

Fernández-Berrocal, P. and Extremera, N. (2006). Emotional intelligence and emotional reactivity and recovery in a laboratory context. Psicothema, 18, Supl., 72-78

Fernández-Berrocal, P., Extremera, N., \& Ramos, N. (2004). Validity and reliability of Spanish modified version of the Trait Meta-Mood Scale. Psychological Report, 94, 47-59.

Gayathri and Meenakshi (2013) a Literature review on Emotional Intelligence, International Journal of Humanities and Social Science Invention, Volume 2 Issue 3. March. 2013, PP.42-51

Gohm, C. L., Baumann, M. R., and Sniezek, J. A. (2001). Personality in Extreme Situations: Thinking (or Not) under Acute Stress. Journal of Research in Personality 35, 388-399.

Goleman, D, Boyatzis, R \& McKee, A. (2002) Primal leadership: Realizing the power of emotional intelligence. Boston: Harvard Business School Press.

Goleman, D. (1995) Emotional intelligence. New York: Bantam.

Goleman, D. (1998) Working with emotional intelligence. New York: Bantam.

Goleman, D. (2004) What makes a leader? Harvard Business Review, 82(1):82-91.

Greensboro, NC: Center for Creative Leadership.

Hafez, M. (2004) "Roles of leadership in organizational change: The case of Egypt." DBA dissertation, Maastricht School of Management (MSM), Netherlands.

Harms, P., \& Credé, M. (2010). Emotional intelligence and transformational and transactional leadership: a metaanalysis. Journal of Leadership \& Organizational Studies, 17(1), 5-17. http://dx.doi.org/10.1177/1548051809350894

Hater, J.J. \& Bass, B.M. (1998). Superiors' evaluations and subordinates' perceptions of transformational and transactional leadership. Journal of Applied Psychology, 73 (4), 695-702.

Higgs, M., and Rowland, D. (2003). Is change changing? An Examination of Approaches to Changes and its leadership, Henley Working paper series, HWP 2003/13.

Howell, J. M., \& Avolio, B. J. (1993). Transformational leadership, transactional leadership, the locus of control and support for innovation: Key predictors of consolidated-business-unit performance. Journal of Applied Psychology, 78, 891-902.

Jordan, P. J., \& Troth, A. C. (2004). Managing emotions during team problem solving: Emotional intelligence and conflict resolution. Human Performance, 17, 195-218.

Jordan, P. J; Ashkanasy, N. M; Hartel, C. E. J \& Hooper, G. (2002) Workgroup emotional intelligence:

Kerr, R, Garvin, J, Heaton, N \& Boyle, E. 2005. Emotional intelligence and leadership effectiveness. Leadership and Organization Development Journal, 27(4):265-279.

Lisa Gardner, Con Stough (2002) Examining the relationship between leadership and emotional intelligence in the senior level manager. Leadership \& organisational development Journal 23:2, 68-78.

Mandell, B., \& Pherwani, S. (2003) the relationship between emotional intelligence and transformational leadership style: A gender comparison. Journal of Business and Psychology, 17(3), 387-404.

Mayer, J. D. and Salovey, P. (1997) what is emotional intelligence? In P. Salovey and D. Sluyter (Eds). Emotional Development and Emotional Intelligence: Implications for Educators (pp. 3-31). New York: Basic Books

Mayer, J. D., Salovey, P., \& Caruso, D. (2000) Models of emotional intelligence. In R. J. Sternberg, (Ed.), Handbook of intelligence (pp. 396-420). New York: Cambridge.

Mayer, J. D., Salovey, P., \& Caruso, D. (2001) Technical manual for the MSCEIT v. 2.0. Toronto,

McKee, A. (2005). Leadership, Passion, and Power: EI, Resonance and Renewal. 5th Annual Emotional Intelligence Conference, Netherlands, 12 - 14 June 
Melita L, Ceasar, D, Anthony, P. Ammeter, M\& Ronald, B., (2003): "Emotional intelligence, leadership effectiveness, and team outcome", The International Journal of Organizational Analysis, Vol. 11 Iss: 1, pp.21 - 40

Naznin, H., (2013) “Correlation between Emotional Intelligence and Transformational Leadership Behaviour.” Journal of Business and Management, 13(2), 64-67.

Of leaders in Florida agriculture, University of Florida, US

Palmer, B, Walls, M, Burgess, Z \& Stough, C. 2001. Emotional intelligence and effective leadership. Leadership and Organization Development Journal, 22(1):5-10.

Ramchunder, Y \& Martins, N. 2014. The role of self-efficacy, emotional intelligence and leadership style as attributes of leadership effectiveness: Original research. SA Journal of Industrial Psychology, 40(1):1-11.

Ruderman, MN, Hannum, K, Leslie, JB \& Steed, JL. 2001. Leadership skills and emotional intelligence.

Sadr, Golnaz. (2012). Emotional Intelligence and Leadership Development. Public Personnei Management, $41(3)$, 535 547.

Salovey, P., Mayer, J. D., Goldman, S. L., Turvey, C., and Palfai, T. P. (1995). Emotional attention, clarity, and repair: Exploring emotional intelligence using the Trait Meta-Mood Scale. In J. W. Pennebaker (Ed.), Emotion, Disclosure, and Health (pp. 125-154). Washington: American Psychological Association.

Scale development and relationship to team process effectiveness and goal focus. Human Resource Management Review, 12, 195 - 214.

Shahin, A. and Wright, P. (2004). "Leadership in the Context of Culture: An Egyptian Perspective", the Leadership and Organization Development Journal, Vol 25, No. 6, pp 499-511.

Sternberg, R. J., \& Vroom, V. H. (2002). The person versus the situation in leadership. Leadership Quarterly, 13, 301323

Strickland, L., (2008) relationship between emotional intelligence and leadership style

Stuart, A., \& Paquet, A. (2001). Emotional intelligence as a determinant of leadership potential. Journal of Industrial Psychology, 27, 30-34.

Tichy, N. M., \& Devanna, M. A. (1996). The transformational leader. New York: Wiley.

Van Knippenberg, D., \& Sitkin, S. B. (2013). A critical assessment of charismatic transformational leadership research: Back to the drawing board? The Academy of Management Annals, 7(1), 1-60. doi: $10.1080 / 19416520.2013 .759433$.

Van Oosten, EB. (2013) The impact of emotional intelligence and executive coaching on leader effectiveness. Unpublished Doctoral dissertation. Case Western Reserve University, Ohio.

Vrba, M. (2007) Emotional intelligence skills and leadership behaviour in a sample of South African first-line managers. Management Dynamics, 16(2): 25-35.

Wang, Y. \& Huang, T., (2009) The relationship of transformational leadership with group cohesiveness and emotional intelligence. Social Behaviour and Personality, 37(3), 379-392.

Yammarino, F.J. and Dubinsky, A.J. (1994)" transformational leadership theory: using levels of analysis to determine boundary conditions", Personnel Psychology, Vol. 47, pp. 787-811.

Bass, B.M., \& Avolio, B.J. (1995). Multifactor leadership questionnaire: Manual leader form, rater and scoring key for ML Q. (pp. 25-835). Redwood city, CA: Mind Garden.

Goleman, D. (1995). Emotional intelligence: why it can matter more than IQ. (pp. 10-35), New York, NY: Bantam.

Faribirzi A, 2003, the impact of transformational leadership on ICT projects in governmental and non-governmental organizations in Mashhad, M.A. thesis of educational management, Isfahan University.

Garner, L., \& Stough, C. (2002). Examining the relationship between leadership and emotional intelligence in senior level managers. Leadership \& organization development journal, 23(2), 46-48.

Day, A.L., New some, S., \& Catano, V.M. (2002). Emotional intelligence and leadership. Canadian Forces Leadership Institute. Saint Mary's Applied Research Team.

Weinberger, L.A. (2003). An examination of the relationship between emotional intelligence, leadership style and perceived leadership effectiveness. Candidate (Ph. D) Dissertation. Human Resource Development Research Center. Swanson \& Associates.

Barling, J., Slater, F., \& Kelloway, E.K. (2000). Transformational leadership and emotional intelligence: An exploratory study. The leadership and organizational Development Journal, 21, 157-161.

Coetzee, C., \& Schaap, P. (2005). The relationship between leadership behavior, outcomes of leadership and emotional intelligence. South African Journal of Industrial Psychology, 31, 31-38. 